\title{
Association of Proton Pump Inhibitors Use and Renal Functions in Elderly
}

\author{
Yaşl1larda Proton Pompa İnhibitörü Kullanımı ve Renal Fonksiyonlarla \\ İlişkisi
}

Alper Alp ${ }^{* 1}$, Sibel Ersan ${ }^{2}$

\begin{abstract}
Introduction: Recently, side effects and especially renal effects of proton pump inhibitors have been pronounced more frequently. It is thought that they may lead to clinical situations as acute tubulointerstitial nephritis, acute kidney injury and progression of chronic kidney injury. In this study, we investigated the frequency of proton pump inhibitor use and its association with proteinuria and kidney injury in older patients admitted to our nephrology outpatient clinic. Methods: The medical records of patients aged 75 years and older who applied to the nephrology outpatient clinic for a period of one year were examined. Results: The frequency of proton pump inhibitors use is high in our 75 years and older patients admitted to the nephrology outpatient clinic. In elderly patients using proton pump inhibitors, the association with chronic kidney injury was found to be more frequent, although not statistically significant. Conclusion: Unaware and/or off-label use of proton pump inhibitors may be associated with impaired renal function. Renal functions should be monitored in patients who have to use a proton pump inhibitor.
\end{abstract}

Key words: Chronic kidney disease, proton pump inhibitors, geriatrics

\section{ÖZET}

Amaç: Son dönemlerde proton pompa inhibitörlerinin yan etkilerinden ve özellikle de renal etkilerinden daha sık söz edilmektedir. Akut tübülointerstisyel nefrit, akut böbrek hasarı, kronik böbrek hasarının progresyonu gibi klinik durumlara neden olabileceği düşünülmektedir. Biz bu çalışmamızda nefroloji polikliniğimize başvuran yaşlı hastalarda proton pompa inhibitörü kullanım sıklığını, proteinüri ve böbrek hasarıyla olan ilişkisini inceledik. Yöntem: Bir yıllık sürede nefroloji polikliniğine başvuran 75 yaş ve üzerindeki hastaların dosyaları incelenmiştir. Bulgular: 75 yaş ve üzeri nefroloji polikliniğine başvuran hastalarımızda proton pompa inhibitörü kullanma sıklığı yüksektir. Proton pompa inhibitörü kullanan yaşlı hastalarda kronik böbrek hasarı birlikteliği istatistiksel olarak anlamlı olmasa da daha sık bulunmuştur. Tartışma: Proton pompa inhibitörlerinin bilinçsiz ve/veya endikasyon dışı kullanımı renal fonksiyonlarda bozulmayla ilişkili olabilir. Proton pompa inhibitörü kullanmak zorunda olan hastalarda renal fonksiyonlar takip edilmelidir.

Anahtar sözcükler: Kronik böbrek hastalı̆̆ı, proton pompa inhibitörleri, geriatri

Received / Geliş tarihi: 05.03.2020, Accepted / Kabul tarihi: 26.05.2020

${ }^{1}$ Muğla Sıtkı Koçman Üniversitesi Tıp Fakültesi, Nefroloji Bilim Dalı, MUĞLA,TÜRKIYYE

${ }^{2}$ SBÜ, Tepecik Eğitim ve Araştırma Hastanesi, Nefroloji Bilim Dalı, İZMİR, TÜRKIYYE

*Address for Correspondence / Yazışma Adresi: Alper Alp, Kötekli Mahallesi Marmaris Yolu üzeri No: 48 Menteşe /MUĞLA/Türkiye -TÜRKIYE, E-mail: alperalp20@hotmail.com

Alp A. Ersan S. Yaşlılarda Proton Pompa İnhibitörü Kullanımı ve Renal Fonksiyonlarla İlişkisi. TJFMPC, 2020;14(3): 403-406.

DOI: $10.21763 / \mathrm{tjfmpc} .698985$ 


\section{GíRiș}

Proton pompa inhibitörleri (PPİ) günlük klinik pratikte sı reçetelenen ilaçların başında gelmektedir. Siklıkla kanıta dayalı olmadan kullanılan bu ilaçların akut interstisyel nefrit (AİN), kronik böbrek hasarına $(\mathrm{KBH})$ neden olabildiği ve altta yatan böbrek hastalığı olanlarda renal progresyonu olumsuz etkilediği son dönemlerde daha sık bildirilmektedir. Özellikle de yüksek doz ve uzun süre kullanımda bu etkinin daha belirgin olduğu belirtilmektedir. Hastanede yatan-özellikle de geriatrik hastalarda-genellikle tedavi şemasına rutin olarak eklenmekte ve taburculuk esnasında da s1klıkla idame tedavi olarak düzenlenmektedir. Belirgin yan etki profilinin olmadığı kanısı bu sık ve yaygın kullanım alışkanlığında en önemli nokta gibi görünmektedir. Bu çalışmada 75 yaş ve üzerindeki hastalarda PPİ kullanımı ile proteinüri ve renal fonksiyonlarla ilişkisi incelenmiştir.

\section{YÖNTEM:}

Ocak-2017 ile Aralık-2017 tarihleri arasında nefroloji polikliniğine başvuran yetmiş beş yaş ve üzeri hastalarda hastane işletim sistemi üzerinden tetkik kodları girilerek, hastaların yaş, cinsiyet, arteriyel tansiyon değerleri, kreatinin seviyeleri, spot idrar protein/kreatinin oranı $(\mathrm{SiP} / \mathrm{K})$ ve/veya 24 saatlik idrarda protein miktarı gibi parametreler kaydedilmiştir. Kronik böbrek hastalığ 1 tanısında; Ulusal Böbrek Vakfi-Böbrek Hastalığı Sonuçları Kalite Girişimi (NFK-DOQI) tanımlama sisteminde üç aydan uzun süre devam eden, sağlığa etkileri olan böbrek yap1 ve fonksiyonundaki anormalliklerden $\left(\mathrm{GFH}<60 \mathrm{ml} / \mathrm{dk} / 1.73 \mathrm{~m}^{2}\right.$, albüminüri $(\geq 30 \mathrm{mg} / 24$ saat), idrar sediment anormallikleri, tübüler bozukluğa bağlı anormallikler, histolojik olarak saptanmış anormallikler, görüntüleme ile saptanmış yapısal anormallikler, böbrek nakli öyküsü) en az biri olarak tanımlanmıştır. Hastalara ait protokol numaraları ile tetkik öncesinde $\geq 30$ gün PPI reçetelenen hastaların sıklığı saptanmıştır. Türkiye'de ticari kullanımda olan tüm PPİ'ler çalışmaya dahil edilmişlerdir. Hastalar tanıları ve/veya PPİ kullanımlarına göre dört gruba ayrılmıştır; kronik böbrek hastalığı olup PPI kullanmayan $(\mathrm{KBH}), \mathrm{KBH}$ olup PPI kullanan (KBH+ PPİ+), sadece PPİ kullanan (PPİ+), KBH olmayan ve PPİ kullanmayan (KBH-PPİ-). Gruplar arasında demografik ve biyokimyasal veriler istatistiksel olarak karşılaştırılmıştır.

İstatistiksel analizlerde IBM SPSS Statistics for Windows, Version 25.0 (Armonk, NY: IBM Corp.) kullanılmıştır. Tüm gruplar arasında değişkenlerin karşılaştırılmasında Kruskal -Wallis varyans analizi kullanılmıştır. $\mathrm{p}<0.05$ istatistiksel anlamlılık olarak kabul edilmiştir. İkili karşıllaştırmalarda Mann-Whitney $U$ testi kullanılmış ve $\mathrm{p}<0.008$ anlamlılık olarak kabul edilmiştir.

\section{BULGULAR}

Poliklinik başvurusunda bulunan toplam 1730 hastadan retrospektif olarak bilgilerine tam ulaşılabilen 146'sı (\%8.4) çalışmaya dahil edilmiştir. Çalışmaya alınan hastaların 80'i (\%54,8) kadın, 66'sı (\%45,2) erkekti. 75-84 yaş arasında 126 hasta $(\% 86,3), 85$ yaş ve üzerinde ise 20 hasta $(\% 13,7)$ mevcuttu. Hastaların yaş ortalaması $79,6 \pm 3,72$ yı1 (min 75-max 87), ortalama kreatinin düzeyi 1,92 $\mathrm{mg} / \mathrm{dl}$ (min 0,7 mg/dl-maks. 7,3 mg/dl) idi. Ortalama sistolik ve diyastolik arteriyel tansiyon değerleri sırasıyla; $142,11 \mathrm{mmHg}$ ve $85,66 \mathrm{mmHg}$ olarak saptandı. Yaş ve cinsiyet dağılımları tüm gruplarda benzer bulundu. Proteinüri ( $\geq 150 \mathrm{mg} /$ gün ve/veya $\mathrm{SiP} / \mathrm{K} \geq 200 \mathrm{mg} /$ gram kreatinin) saptanan hasta sıklığ $\%$ 70,54 (103 hasta) ve PPİ kullanım sıklığ \%61,6 (90 hasta) olarak bulundu. İleri yaş grubu değerlendirildiğinde 85 yaş ve üstü ile altındaki hastalar arasında proteinüri açısından anlamlı farklılık saptamadık $(p=0,486)$. Tüm hastaların ortalama proteinüri düzeyi $835,49 \mathrm{mg} / \mathrm{dl}$ idi. Gruplara göre ortalama proteinüri ve kreatinin düzeyleri sirasıyla; KBH grubunda (32 hasta) $1241,24 \pm 1282,35 \mathrm{mg} / \mathrm{gr}, \quad 1,99 \pm 0,84 \mathrm{mg} / \mathrm{dl}$; $\mathrm{KBH}+\mathrm{PPI}+$ grubunda (56 hasta) $1114,26 \pm 1183,54$ $\mathrm{mg} / \mathrm{gr}, 2,42 \pm 1,27 \mathrm{mg} / \mathrm{dl}$; PPİ+ grubunda (34 hasta) $463,61 \pm 611,26 \mathrm{mg} / \mathrm{gr}, 1,45 \pm 0,65 \mathrm{mg} / \mathrm{dl}$ ve $\mathrm{KBH}-$ PPİ- grubunda (24 hasta) $170,86 \pm 229,55 \mathrm{mg} / \mathrm{gr}$, $1,30 \pm 0,29 \mathrm{mg} / \mathrm{dl}$ saptand1. İstatistiksel analizlerde tüm gruplar arasında proteinüri ve kreatinin değerleri anlamlı olarak farklı bulundu $(\mathrm{p}<0.05)$. İkili karşılaştırmalarda; $\mathrm{KBH}$ ve $\mathrm{KBH}+\mathrm{PPI}+$ grupları arasında proteinüri ve kreatinin düzeylerinde anlamlı fark tespit edilmedi $(\mathrm{p}=0.86, \quad \mathrm{p}=0,14)$. $\mathrm{KBH}+/ \mathrm{KBH}+\mathrm{PPI}+$ gruplar1 ile PPİ+/KBH-PPİgrupları arasında kreatinin ve proteinüri düzeyleri PPİ+/KBH-PPİ- gruplara göre istatistiki olarak anlamlı daha yüksekti $(\mathrm{p}<0.05)$. PPİ+ ile KBH-PPİgrupların karşılaştırılmasında PPİ+ grupta proteinüri düzeyi istatistiki olarak anlamlı yüksek $(p=0.049)$, kreatinin düzeyleri PPİ+ grupta daha yüksek olmasına rağmen istatistiksel olarak anlamlı fark yoktu.

\section{TARTIŞMA}

Kronik böbrek hasarı sıklığı tüm dünyada giderek artmaktadır. Global prevalansının \%8-16 civarında olduğu tahmin edilmektedir. ${ }^{1}$ Sebeplerine bakıldığında diabetes mellitus, hipertansiyon, polikistik böbrek hastalığı ve glomerülonefritler ön planda yer almaktadır. Bununla birlikte nedeni belli olmayan etiyolojiler de önemli bir yer tutmaktadır. Kronik böbrek hasarı geliştikten sonra progresyonun yavaşlatılmasında; diyet önerilerine uyulması, sık1 kan basınc1 kontrolü, proteinürinin azaltılması, sigaranın birakılması, hiperlipideminin tedavisi bilinen efektif yöntemlerdir. Tüm bu önleme seçeneklerinin yanında nefrotoksik ajanlardan kaçınmak hastalığın her evresinde çok önemlidir. Günümüzde nefrotoksik olduğu bilinen veya 
nefrotoksik etkileri yeni anlaşılan birçok ilaç bulunmaktadır ve hastaların takibinde ve değerlendirilmesinde mutlaka sorgulanmalıdır.

PPI'ler tüm dünyada çok yaygın kullanılmaktadır. ABD'de en çok reçete edilen ilaçların ilk 10'unda PPİ'ler çoğunlukla bulunmaktadır. Mide mukozasındaki parietal hücrelerde $\mathrm{H}+/ \mathrm{K}+\quad$ ATPaz'n inreversible inhibisyonu ve böylece gastrik asit sekresyonunun azaltılmasıyla etki gösterir. Peptik ülserde, gastroözofajiyal reflünün tedavisinde, Zollinger Ellison sendromunda, nonsteroidal antiinflamatuar ilaçlarla ilişkili ülserde, Helicobacter pilori eradikasyonunda etkin rol oynamaktadırlar ve mutlak endikasyonları mevcuttur. Türkiye'de de reçetesiz kullanım olanağı olan PPİ grubu ilaçların kullanımı çok yaygındır. Uzun süre ciddi yan etkilerinin olmadığı düşünülmekteydi, fakat son dekatlarda güvenilirlik hakkında farklı görüşler ortaya çıkmıştır. Osteoporoz ve kırık riskinde artış, enfeksiyon riskinde artış (özellikle pnömoni ve Clostridium difficile enfeksiyonu, spontan bakteriyel peritonit), akut böbrek hasarı $(\mathrm{ABH}) /$ kronik böbrek hasar1 $(\mathrm{KBH})$, hipomagnezemi, vitamin B12 eksikliği, artmış kardiyovasküler hastalık riski gibi etkilerinden daha sık söz edilmeye başlanmıştır. Özellikle de KBH ile olan ilişkisi son yılların güncel konularından birisidir. Çalışmamızda da yaşlılarda (75 yaş ve üzeri) PPİ reçetelenme oranının yüksek olduğu $(\% 61,6)$ ve KBH olmasa bile PPI kullanımının proteinüri riskini PPİ kullanmayan kontrol grubuna göre arttırdığı gösterilmiştir. Proteinüride artış endotel disfonksiyonunun göstergelerinden birisidir ve artmış kardiyovasküler mortaliteyle ilişkisi iyi bilinmektedir. Proteinüri düzeyinin azaltıcı tedavinin değişik hasta gruplarında (hipertansiyon, diyabetes mellitus vs.) mortaliteyi azaltıcı etkileri de birçok büyük çalışmada ispatlanmıştır. Çalışmamızda da proteinüri miktarının PPİ kullanımıyla olan pozitif ilişkisi gösterilmiştir. Bu açıdan, özellikle kanıta dayalı olmayan ve endikasyonu şüpheli olan PPI kullanımından kaçınılması gerektiğini ifade edebiliriz.

Hipomagnezemi, $\mathrm{ABH}$, insidental kronik böbrek hastalığı, KBH'nin progresyonu gibi etkilerinin yanında PPI'lerin kanıtlanmış en iyi bilinen renal etkisi AİN'dir. ${ }^{2}$ Birçok çalışmada AİNPPİ ilişkisi gösterilmiştir. ${ }^{3,4} \mathrm{ABH}$ etiyolojisinde de ön planda AİN suçlanmıştır. Özellikle de geriatrik hastalardaki AIIN en s1k sebebinin PPI'ler olduğu belirtilmektedir. ${ }^{5}$ Tekrarlayan karakterde olabilir. AİN'den sonra tam renal düzelmenin sağlanamadığı literatürde gösterilmiştir. ${ }^{6}$ Klasik hipersensitivite bulguları çoğunlukla eşlik etmez (raş, ateş, eozinofili birlikteliği), bu yüzden klinik farkındalık düşük olabilir. Histopatolojik bulgular ve tedavi yönetimi diğer AİN yapan ilaçlardan farklı değildir. Her ne kadar renal replasman tedavisi gerektiren böbrek hasarı çok nadir görülse de önemli bir oranda hastada tam renal iyileşmenin görülmediği saptanmıştır. Bunun dışındaki nefrotoksik etkiler net değildir. Bozulmuş lizozomal asidifikasyon ve protein homeostazisi, hipomagnezemi gibi etmenler suçlanmış ve bunların insan renal hücrelerinde oksidatif stres artışı ve disfonksiyona yol açabileceği ileri sürülmüştür. Eğer bir hastada PPİ ilişskili AİN öyküsü mevcutsa tekrar (başka bir molekül de olsa) PPİ başlanması sakıncalı olabilir. $\mathrm{Bu}$ hastalarda alternatif tedavilere yönelmek en doğrusudur $\left(\mathrm{H}_{2}\right.$ reseptör blokerleri gibi). Çalışmamızda KBH tanılı hastaların da patofizyolojisinde AİN olması yüksek ihtimaldir. PPI'ler ile etkileşime girebilecek ilaç kullanımı çalışmamızda karıştırıcı faktör olarak değerlendirilmemiştir, bununla birlikte nefrotoksisite potansiyeli olan ilaçları kullanan hastalar çalışmaya dahil edilmemiştir. Böylece PPI'lerin olası renal etkilerini daha net bir şekilde ortaya koymak amaçlanmıştır.

Tayvan'da-ki globalde son dönem böbrek yetmezliği yıllık insidansının ve prevalansının en yüksek olduğu ülke-16.704 yeni tanı KBH tanılı hastada yapılan vaka-kontrol çalışmasında PPİ

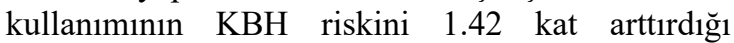
gösterilmiştir (\%29.8'e karş1 \%23.1, chi-square testi, $p<0.001){ }^{7}$ Antoniou ve ark., 66 yaş ve üzerindeki hastaların PPİ başlandıktan sonraki 120 gün içerisinde akut böbrek hasarı nedeniyle hastaneye başvurmalarını incelemişler ve PPİ kullananlarda kullanmayanlara göre 2 kat daha fazla $\mathrm{ABH}$ görüldüğünü tespit etmiştirler. ${ }^{8}$ Geniş bir İsveç kohort çalışmasında $\left(9.578 \mathrm{H}_{2}\right.$ reseptör blokeri kullanıcısı, 105.305 PPİ kullanıcısı-ortalama 2.7 y1 izlem süresi) yeni PPI kullanmaya başlayan hastalarda $\mathrm{H}_{2}$ reseptör blokeri kullanan hastalara göre $\mathrm{KBH}$ progresyonunun arttığı ve kümülatif maruziyetle bu advers etkinin daha da arttı̆ 1 gösterilmiştir. ${ }^{9}$ Bir metaanalizde PPİ kullanımının $\mathrm{H}_{2}$ reseptör blokerlerine göre $\mathrm{KBH}$ ve/veya SDBY gelişme riskini 1.3 kat arttırdığ1 gösterilmiştir. ${ }^{10}$ Yine renal transplant hastalarında yapılan bir çalışmada uzun dönem izlemde PPI kullanan hastalarda kullanmayanlara göre daha yüksek kreatinin seviyeleri saptanmıştır. ${ }^{11}$ Poncelas ve ark.'nın, birinci basamak sağlık hizmetine başvuran ve KBH'lı hastaların dahil edilmediği toplum bazlı retrospektif kohortta hem doz bağımlı artış hem de uzamış ilaç maruziyetinin insidental KBH gelişimini arttırdığı gösterilmiştir. ${ }^{12}$ Farklı bir görüş olarak bazı hastalarda insidental $\mathrm{KBH}$ etiyolojisinde $\mathrm{ABH}$ veya AİN öyküde yer almadığı ve direkt bir yolun söz konusu olabileceği Xie ve ark.' ’n çalışmasında gösterilmiştir. ${ }^{13}$ Bizim çalışmamızda da KBH+PPİ+ grubundaki hastalarda $\mathrm{KBH}+\mathrm{PPI}$ kullanmayan gruba göre kreatinin seviyeleri her ne kadar istatistiksel olarak anlamlı olmasa da daha yüksek saptanmıştı. $\mathrm{Bu}$ etkinin ileri yaş hastalarda da mevcut olduğunu gösterdik. Bu sonuç son dönemde bahsedilen PPI ile KBH ilişkisini vurgulayan literatürle uyumluydu. 
Birçok çalışmada gereksiz ve uygun olmayan PPİ kullanımının yaygın olduğu-KBH hastalarında da-gösterilmiştir. ${ }^{14,15,16}$ Biz PPI kullanımı için minimal süreyi aralıksız en az 30 gün olarak belirledik ve veri sisteminden de bunu teyit ettik. Bunu çalışmamızın kısıtlılığı olarak belirtebiliriz. Antoniou ve ark., çalıșmalarında bu süreyi en az 120 gün olarak belirlemişlerdir. ${ }^{8}$ Blank ve ark. ise çalışmalarında, çalışmamızla uyumlu olarak en az 30 gün boyunca PPİ kullanan hastaları da dahil etmişlerdir. ${ }^{17}$ PPI ilişkili renal hasarlanmanın çoğunlukla AİN'ye bağlı olduğu varsayılırsa bu süre olası gibi görünmektedir. PPİ kullanımın renal yan etkileri hakkında yeni çalışmalar, kanıtlar sunulmaktadır. Henüz hangi risk grubundaki hastalarda daha fazla renal toksik etkilerinin görülebileceği, hangi PPI'lerin daha fazla hasar yapıc1 etkisinin olduğu, hangi dozlarda bu etkinin ortaya çıkabildiği gibi konular netlik kazanmamıştır. Çalışmamızda PPİ'ların genel grup etkisi araştırılmıştır. Örneklem grubunun istatiksel olarak nispeten küçüklüğü de göz önüne alınarak PPI'lar ayrı ayrı incelenememiştir.

Belki de en uygun yaklaşım kanıta dayalı olmayan, gereksiz ve bilinçsiz PPİ kullanımından uzak durmaktır. Biz de polikliniğimizde takipli $\mathrm{KBH}$ hastalarımızda progresyon riskini göz önünde bulundurarak, mutlak endikasyonu olmaması halinde, PPİ kullanımının sonlandırabileceği yönünde hastalarımıza bilgilendirme yapmaktayız. PPİ kullanan hastalardaki mutlak veya rölatif endikasyonlar, kullanım süresinin yeterliliği gibi konular analitik olarak değerlendirilmelidir. ${ }^{18}$ Ayrıca uzun dönem PPİ kullanım endikasyonu olan hastaların renal fonksiyonlarının periyodik takibi önerilmeli, hastalar bu konuda bilinçlendirilmelidir. Bir diğer yaklaşım da özellikle de Türkiye için reçetesiz PPİ kullanımının sorgulanması olmalıdır.

\section{KAYNAKLAR}

1. Jha V, Garcia-Garcia G, Iseki K, et al. Chronic kidney disease: global dimension and perspectives. Lancet. 2013; 382: 260-272.

2. Ruffenach SJ, Siskind MS, Lien YH. Acute interstitial nephritis due to omeprazole. Am J Med. 1992; 93: 472-473.

3. Simpson IJMM, Pilmore H, Manley P, Williams L, Thein H, Voss D. Proton pump inhibitors and acute interstitial nephritis: report and analysis of 15 cases. Nephrology 2006; 11: 381-385.

4. Geevasinga N, Coleman PL,Webster AC, Roger SD. Proton pump inhibitors and acute interstitial nephritis. Clin Gastroenterol Hepatol. 2006; 4: 597604.
5. Sierra F, Suarez M, Rey M et al. Systematic review: proton pump inhibitör associated acute interstitial nephritis. Aliment Pharmacol Ther 2007; 26: 545553.

6. Praga M, Gonzalez E. Acute interstitial nephritis. Kidney Int 2010; 77: 956-961.

7. Shih-Chang Hunga, Kuan-Fu Liaob, Hung-Chang Hunge, Cheng-Li Ling, Shih-Wei Laig, Po-Chang Leej, Shih-Rong Hung. Using proton pump inhibitors correlates with an increased risk of chronic kidney disease: a nationwide database-derived case controlled study. Family Practice, 2018; 35: 166-171.

8. Antoniou T, Macdonald EM, Hollands S et al. Proton pump inhibitors and the risk of acute kidney injury in older patients: a population-based cohort study. CMAJ Open 2015; 3: E166-71.

9. Klatte DCF, Gasparini A, Xu H, de Deco P, Trevisan M, Johansson ALV, Wettermark B, Ärnlöv J, Janmaat CJ, Lindholm B, Dekker FW, Coresh J, Grams ME, Carrero JJ. Association Between Proton Pump Inhibitor Use and Risk of Progression of Chronic Kidney Disease. Gastroenterology. 2017;153: 702-710.

10. Karn Wijarnpreecha, Charat Thongprayoon, Supavit Chesdachai, Panadeekarn Panjawatanana, Patompong Ungprasert, Wisit Cheungpasitporn. Associations of Proton-Pump Inhibitors and $\mathrm{H} 2$ Receptor Antagonists with Chronic Kidney Disease: A Meta-Analysis. Dig Dis Sci. 2017; 62: 2821-2827.

11. Uludag O, Mirioglu S, Dirim A, Akardere O, Akyildiz A, Sever M, Caliskan Y. Effects of proton pump inhibitors on kidney transplant recipients. Nephrol Dial Transplant 2017; 32 suppl 3: iii730.

12. Rodriguez-Poncelas A, Barcelo MA, Saez M, Collde-Tuero G. Duration and dosing of proton pump inhibitors associated with high incidence of chronic kidney disease in population-based cohort. PloS One. 2018; 13: e0204231.

13. Xie Y, Bowe B, Li T, Xian H, Yan Y, Al-Aly Z. Long-term kidney outcomes among users of proton pump inhibitors without intervening acute kidney injury. Kidney Int. 2017; 91: 1482-1494.

14. Forgacs I, Loganayagam A. Overprescribing proton pump inhibitors. BMJ. 2008; 336: 2-3.

15. Strid H, Simren M, Bjornsson ES. Overuse of acid suppressant drugs in patients with chronic renal failure. Nephrol Dial Transplant. 2003; 18: 570-575.

16. Lee HJ, Lee H, Oh SH, et al. Chronic kidney disease (CKD) patients are exposed to more proton pump inhibitor (PPI)s compared to non-CKD patients. PloS One. 2018; 13: e0203878.

17. Blank ML, Parkin L, Paul C, Herbison P. A nationwide nested case-control study indicates an increased risk of acute interstitial nephritis with proton pump inhibitor use. Kidney Int. 2014; 86(4): 837-844.

18. Farrell B, Pottie K, Thompson W, et al. Deprescribing proton pump inhibitors: evidencebased clinical practice guideline. Can Fam Physician. 2017; 63: 354-36 